\title{
GENOTOXIC AND HISTOPATHOLOGICAL EVALUATION OF ZINC OXIDE NANORODS IN VIVO IN SWISS ALBINO MICE
}

\author{
Vishnu Sravan Bollu1, Geeta Soren², Kaiser Jamil33, Agaiah Bairi' ${ }^{4}$ Sridhar Yashmaina ${ }^{5}$ \\ ${ }^{1}$ Research Student, Department of Pharmacology, SRR College of Pharmaceutical Sciences, Karimnagar. \\ ${ }^{2}$ Associate Professor, Department of Pharmacology, Maheshwara Medical College \& Hospital, Patancheru. \\ ${ }^{3}$ Head, Department of Genetics, Bhagwan Mahavir Medical Research Centre, Hyderabad. \\ 4 Principal, Department of Pharmaceutics, SRR College of Pharmaceutical Sciences, Karimnagar. \\ 5 Professor, Department of Pharmacology, KGR Institute of Technology and Management, Rangareddy.
}

\section{ABSTRACT}

\section{BACKGROUND}

Zinc oxide ( $\mathrm{ZnO})$ nanoparticles are manufactured worldwide in large quantities for use in wide range of applications including pigments and cosmetic manufacturing. Although $\mathrm{ZnO}$ is chemically inert, $\mathrm{ZnO}$ nanoparticles can cause negative health effects. However, the mechanism involved in $\mathrm{ZnO}$ induced genotoxicity and carcinogenicity has not been clearly defined and are poorly studied in vivo.

\section{MATERIALS AND METHODS}

The present study evaluated the genotoxicity of $\mathrm{ZnO}$ nanoparticles that were dispersed in drinking water and administered orally to mice for a period of 7 days. The standard genotoxicity testing parameters, peripheral blood micronucleus assay, alkaline comet assay and chromosomal aberration assay were employed.

\section{RESULTS}

The percent incidence of micronucleated polychromatic erythrocytes, increase in comet tail length and structural chromosomal aberrations were determined and the results were statistically analysed. Together, these results demonstrated that ZnO NPs administered orally caused no genetic instability in mice. Further, the histopathological studies conducted at the same doses showed no toxicity in liver, heart, kidney and spleen tissues.

\section{CONCLUSIONS}

In conclusion, these results indicate that ZnO NPs exposed orally at $0.5 \mathrm{mg} / \mathrm{kg}, 1 \mathrm{mg} / \mathrm{kg}, 2 \mathrm{mg} / \mathrm{kg}, 4 \mathrm{mg} / \mathrm{kg}, 6 \mathrm{mg} / \mathrm{kg} \mathrm{dose} \mathrm{were}$ not genotoxic.

\section{KEYWORDS}

Zinc Oxide Nanoparticles, Genotoxicity, Micronucleus Assay, Comet Assay, Chromosomal Aberration Assay, Histopathology.

HOW TO CITE THIS ARTICLE: Bollu VS, Soren G, Jamil K, et al. Genotoxic and histopathological evaluation of zinc oxide nanorods in vivo in Swiss albino mice. J. Evolution Med. Dent. Sci. 2016;5(83):6186-6192, DOI: 10.14260/jemds/2016/1398

\begin{abstract}
BACKGROUND
Zinc Oxide $(\mathrm{ZnO})$ in nanoparticulate form has gained considerable attention in recent years for their potential applicable properties.[1] It is one of the agent used to provide opaqueness in products like paints and pigments. The antibacterial properties of $\mathrm{ZnO}$ extended its use in manufacturing textiles ${ }^{[2]}$ and food packing. Also used as a photocatalytic degrader in water purification, as a gas sensor[3] for detecting pollutants, toxic gases[4] and alcohol. Therapeutically $\mathrm{ZnO}$ is used as a drug carrier, endodontic medication. Apart from these, its potential applications are in area of cosmetics, [5] where it is used as a sunscreen aid. Currently, consumer products containing $\mathrm{ZnO}$ nanoparticles are increasing rapidly. This demands wide scale production, concurrently elevating the exposure level of these
\end{abstract}

Financial or Other, Competing Interest: None.

Submission 11-09-2016, Peer Review 05-10-2016,

Acceptance 11-10-2016, Published 15-10-2016.

Corresponding Author:

Dr. Sridhar Yashmaina,

Professor,

Department of Pharmacology and Toxicology,

KGR Institute of Technology and Management,

Rampally, Keesara, Rangareddy-501301.

E-mail: sridhar.yashmaina@gmail.com

DOI: $10.14260 /$ jemds/2016/1398 nanoparticles. According to US-EPA guidelines for carcinogen risk assessment 2005, ZnO has been categorised in group-D (Not classifiable as human carcinogen) based on inadequate evidence of carcinogenic studies in humans and animals. Moreover, this commonly refers to materials in the microns to larger size range. As even these substances when reduced to the nanoscale can develop new actions of toxicity.

In this regard, several studies pertaining to toxicity of $\mathrm{ZnO}$ have been conducted. In vitro toxicological studies on primary mouse embryo fibroblast cells,[6] on human bronchoalveolar derived cells (A549),[7] on mouse neural stem cells ${ }^{[8]}$ and on primary rat alveolar epithelial cell monolayers, showed ZnO NPs were cytotoxic, irrespective of their particle size. In vivo studies showed major organs damage by ZnO NPs of $20 \mathrm{~nm}$ and $120 \mathrm{~nm}$ size evident from serum biochemical and pathological estimations. ZnO NPs also found to alter normal physiological functions of major metabolic organs, when administered orally at $2.5 \mathrm{~g} / \mathrm{kg}$.

These in vivo studies correlate the toxicity of ZnO NPs at higher doses. But ZnO NPs employed in cosmetics, food packing, textiles, paints, water remediation process may inevitably expose at low doses to humans. And the potential toxicological impact at that dose level relevant to human exposure is of major task to assess their safety evaluation.

As a part of cancer risk assessment, the genotoxic studies are gaining rapid importance. Two recent studies show a 
direct chemical interaction between $\mathrm{ZnO}$ nanoparticles and DNA, through the DNA phosphate group, but a link to mutagenesis has not been proven. On the other hand, studies have showed indirect DNA damage through inflammation and generation of reactive oxygen species by $\mathrm{ZnO}$ nanoparticles.[9] Ames test performed by[10] using $\mathrm{ZnO}$ nanoparticles capped with tetramethylammonium hydroxide (TMAOH), on Chinese Hamster Ovary (CHO) cells, showed no mutagenicity. Clastogenicity was observed in $\mathrm{CHO}$ cells at all concentrations of $\mathrm{ZnO}(100 \mathrm{~nm})$ used.[11] A study on Human sperm cells at $\mathrm{ZnO} 40 \mathrm{~nm} \& 70 \mathrm{~nm}$, showed dose dependent increase in DNA damage in pre-irradiated (PI) \& simultaneous irradiated (SI) conditions.[12] Chromosomal aberrations were observed in human dental pulp cells with zinc oxide formulations intended for dental fillings.[13] Human lymphocytes DNA damage was observed with ZnO NPs of size less than 20 nm.[14] These studies were conducted in vitro in cultured cells. Majority of results show that $\mathrm{ZnO}$ nanoparticles are genotoxic in various cell lines, with minor reporting to be not. The rationale for these conflicting results is not clear, and it may be due to different cell types, concentrations, and nanoparticle sizes that have been employed.

Thus far, most nanoparticle genotoxicity studies have focused on in vitro conditions, the relevance to human exposure correlating from in vivo studies is required to access the $\mathrm{ZnO}$ toxicity. Accordingly, $\mathrm{ZnO}$ nanorods genotoxic evaluation administered orally in Swiss mice for a 7 day period with the lowest possible inevitable exposure doses was aimed. Doses at range of $0.5 \mathrm{mg} / \mathrm{kg}, 1 \mathrm{mg} / \mathrm{kg}, 2 \mathrm{mg} / \mathrm{kg}, 4$ $\mathrm{mg} / \mathrm{kg}$, and $6 \mathrm{mg} / \mathrm{kg}$ are selected based on the criteria that nanoparticles are more affective at low doses compared to bulk counterpart and are more relevant unknown exposure doses. In order to assess DNA damage, alkaline comet assay was employed to evaluate DNA strand break, micronucleus assay and chromosomal aberration assay to evaluate chromosomal damage.

\section{MATERIALS AND METHODS \\ Materials}

ZnO nanorods powder was obtained from "International Advanced Research Center for Powder Metallurgy and New Materials", Hyderabad as a gift sample. The details of characterisation are listed in Table 1 . All the chemicals used for the experimental analysis are of analytical grade.

\section{Mice}

Male Swiss albino mice of seven weeks old were procured from Sainath Laboratory (Hyderabad, India) with prior approval from Institutional animal ethics committee (No.1004./SRRCOPSc/KNR/IAEC/2011).

For a period of one week, the animals were acclimatised to laboratory environment with food and water available ad libitum. Thirty six mice with six in each dose group were employed. Group I served as normal control, which received drinking water. The treatment groups II, III, IV, V, VI received doses of ZnO NPs at $0.5 \mathrm{mg} / \mathrm{kg}, 1 \mathrm{mg} / \mathrm{kg}, 2 \mathrm{mg} / \mathrm{kg}, 4 \mathrm{mg} / \mathrm{kg}, 6$ $\mathrm{mg} / \mathrm{kg}$ at a dose volume of $1 \mathrm{~mL} / 100 \mathrm{~g}$ body weight of mice for a period of seven days with 24 hours' time interval between each dose. Groups II to VI are employed for micronucleus assay and comet assay. Blood sampling for micronucleus assay and comet assay was done after 36 hours by tail vein puncture, the blood sample collected before treatment for these groups serves as control. Bone marrow was collected from both the femurs of mice after 48 hours following final treatment for chromosomal aberration assay and the samples of untreated group served as control respectively.

\section{Treatment Protocols}

Solutions of dispersed ZnO NPs were prepared by ultrasonication (Sonic "Vibra-Cell") for 10-15 min. in drinking water[15] at concentrations of $50,100,200,400,600 \mu \mathrm{g} / \mathrm{mL}$, and administered to mice of respective groups. The exposure was for seven days. Groups treated with drinking water served as control. All the experiments were performed as per CPCSEA guidelines.

\section{In Vivo Micronucleus Assay}

The micronuclei assay was done as described by Westbrook et al 2009.[16] Three microlitre aliquots of the peripheral blood were collected as described above and smeared on slides. Four smears were made for each sample, and stained with Giemsa stain for $1.5 \mathrm{~min}$. Reverse of the slides were cleaned with Methanol before air drying. Air dried slides were mounted permanently with cover glass. All slides were independently coded before microscopic (Oil immersion objective) analysis. Two thousand polychromatic erythrocytes (PCEs) were scored and concurrently met micronucleated polychromatic erythrocytes (MnPCEs) were recorded and expressed as percentage incidence. Another 1000 erythrocytes were recorded separately and simultaneously met polychromatic erythrocytes (PCEs) and normochromatic erythrocytes (NCEs) were counted to express NCE\% and micronucleated normochromatic erythrocytes (MnNCEs\%). Cytotoxic parameters; percentage of polychromatic erythrocytes (PCEs\%) and ratio of polychromatic erythrocytes to normochromatic erythrocytes $(\mathrm{P} / \mathrm{N})$, are also calculated.

\section{Alkaline Comet Assay}

The blood sample collected for micronucleus assay was employed for comet assay. The slides were prepared as per procedure mentioned by Chuang et al 2004[17] using whole blood sample for single gel electrophoresis/comet assay with slight modification in the time to be exposed to lysing solution. The samples collected before treatment serves as control. The slides were coated with three layers of agarose; the bottom layer was composed of $0.67 \%$ NMA, second (Middle) layer consisted of $0.5 \%$ LMA mixed with 5-10 $\mu \mathrm{L}$ of blood sample and third and upper most layer with $80 \mu \mathrm{L}$ of $0.5 \%$ LMA. The slides were then kept in lysis buffer [2.5 M $\mathrm{NaCl}, 100 \mathrm{mM}$ EDTA, $10 \mathrm{mM}$ Tris- $\mathrm{HCl}, 10 \%$ DMSO (Added freshly) and 1\% Triton X-100 (Added freshly); with $\mathrm{pH}$ adjusted to 10 for 12-24 hours. Slides then were incubated for $20 \mathrm{~min}$. in electrophoresis buffer (100 mM EDTA, $300 \mathrm{mM}$ $\mathrm{NaOH}$; $\mathrm{pH}>13$ ) prior to electrophoresis at $25 \mathrm{~V}$ and $300 \mathrm{~mA}$ for 1 hour. After electrophoresis, the slides were washed thrice with neutralisation buffer $(0.4 \mathrm{M}$ Tris-HCl; $\mathrm{pH}>7.5)$ and were air dried. Subsequently, silver staining was carried out by the procedure of Nadin et al 2001.[18] Briefly, air-dried slides were immersed in fixing solution $(75 \mathrm{~g}$ trichloroacetic acid, $25 \mathrm{~g}$ Zinc sulphate and $25 \mathrm{~g}$ glycerol in $500 \mathrm{~mL}$ distilled water) for $10 \mathrm{~min}$. and washed with double-distilled water 6 8 times before they were air dried for about 1 hour. $68 \mathrm{~mL}$ of staining solution B (100 mg ammonium nitrate, $100 \mathrm{mg}$ silver 
nitrate, $500 \mathrm{mg}$ tungstosilicic acid, and $250 \mu \mathrm{L}$ of formaldehyde in $500 \mathrm{~mL}$ double-distilled water) was mixed with $32 \mathrm{~mL}$ of staining solution A ( $25 \mathrm{~g}$ sodium carbonate in $500 \mathrm{~mL}$ double-distilled water) and poured into a Coplin jar. The slides were dipped vertically into these Coplin jars until a greyish colour developed on the slides. Staining was stopped by dipping the slides in stopping solution $(1 \%$ glacial acetic acid) for $5 \mathrm{~min}$. The whole procedure was carried out in a dim light to minimise artificial DNA damage. Microscopically $(45 \times)$, a minimum of 100 comets were scored per animal (50 in each of two replicate slides). All the slides were coded before evaluation. Comet head diameter and total comet length were measured using an ocular micrometre which was calibrated with the help of a stage micrometre, and tail length was calculated by the formula. Comet Tail length=Total comet length-Head diameter.

\section{In Vivo Chromosome Aberration Assay}

Following the treatment with test substance $\mathrm{ZnO}$ nanoparticle dispersion, each group is subjected to sampling for chromosome preparation. $0.2 \mathrm{~mL}$ of $0.02 \%$ colchicine was injected intraperitoneally into each animal to arrest cells in the metaphase of cell cycle. After two hours of injection, the animals were sacrificed by lethal dose of anaesthesia. Through proper surgical procedure, both the femurs of mice were collected. The marrow was aspirated from femur into a syringe containing hypnotic solution. The marrow suspension was incubated at $37^{\circ} \mathrm{C}$ for $15-20 \mathrm{~min}$. and centrifuged at 1000 rpm for $10 \mathrm{~min}$. The supernatant was discarded and the pellet was mixed with the fixative (3:1, methanol and acetic acid) and the suspension was allowed to stand for $30 \mathrm{~min}$. and then centrifuged. The preparation was given two changes of fixative until the pellet changes into white colour. Finally, the pellet was mixed thoroughly in $1 \mathrm{~mL}$ fresh fixative and 2-3 drops of the suspension was placed on a clean glass slide from height. The slides were flame dried and stained with $10 \%$ Giemsa at $\mathrm{pH} 6.8$ for $15-20 \mathrm{~min}$. All slides, including those of treatment and negative controls, were independently coded before microscopic analysis. The slides were screened for chromosomal abnormalities as per standard method mentioned by Savage 1976[19] via observing under oil immersion objective. About 100 well-spread metaphase plates were scored per animal in groups under study and all the observed aberrations were recorded and evaluated by comparing with untreated control group. The mitotic index was determined as a measure of cytotoxicity in at least 1000 cells per animal along with chromosomal aberrations for all treated animals and untreated negative control animals.

\section{Statistical Analysis}

Data were expressed as Mean \pm SEM for micronucleus assay and comet assay, and Mean \pm SD for chromosomal aberration assay. Statistical analysis was executed using Graph pad prism version 4, California, USA. Data analysis with in group was carried out by Students paired-t test and between groups by Students unpaired - $t$ test and overall by one way ANOVA followed by Dunnett's post hoc test.

\section{RESULTS \\ In Vivo Micronucleus Assay}

The incidence of micronuclei serves as an index of clastogenicity. The incidence $\%$ of micronucleated polychromatic erythrocytes (MnPCEs) and micronucleated normochromatic erythrocytes were not varied significantly after treatment with $\mathrm{ZnO}$ NPs when compared to that of before treatment. Similarly, two cytotoxic parameters polychromatic erythrocyte percentage and ratio of polychromatic to normochromatic erythrocytes also showed no significant difference after treatment with ZnO NPs for a period of 7 days. This result showed that ZnO NPs to have no genotoxic potential at selected doses. The values are represented in Table 2.

\section{Alkaline Comet Assay}

DNA strand breaks were measured by alkaline comet assay in mice peripheral blood before and after treatment. The average tail length of comets observed after treatment with $\mathrm{ZnO}$ NPs in the treatment groups was not found to vary significantly with that before treatment values. The result thus demonstrates no significant DNA stand break as was evident in mice treated with ZnO NPs. The results are represented in Table 3.

\section{Chromosomal Aberration Assay}

The structural chromosome aberrations serve as index mutagenicity of test material. More the number of aberrations higher are the chances to be mutagenic. The frequency of structural chromosomal aberrations (SCAs) was found to increase slightly with increasing doses, but was not statistically differed from that of control. The percentage mitotic index, sign of cytotoxicity also not varied significantly. These indicate that ZnO NPs have not caused considerable chromosomal damage. The values are represented in table 4 .

\section{Histopathological Studies}

Histopathological findings of tissues under examination, liver, heart, kidney, and spleen of untreated and treated groups showed no evident tissue damage, with increase in dose of ZnO NPs. But with some exceptions of damage in liver tissue of $1 \mathrm{mg} / \mathrm{kg}$ treated group with foamy degenerative hepatocytes and spleen tissue of $2 \mathrm{mg} / \mathrm{kg}$ treated group with irregular dilated vascular channels surrounded by benign spindle cells. Histopathological images of liver, heart, kidney and spleen tissues represented in Figures 1-4 respectively.

\begin{tabular}{|c|c|}
\hline Character & Details \\
\hline Shape & Rod shaped \\
\hline Size & $18-20 \mathrm{~nm}$ \\
\hline Surface area & $30 \mathrm{~m}^{2} / \mathrm{g}$ \\
\hline Aspect Ratio & $\approx 3-4$ \\
\hline \multicolumn{2}{|c|}{ Table 1: Characterisation details of zinc oxide nanorods } \\
\hline
\end{tabular}




\begin{tabular}{|c|c|c|c|c|c|c|c|c|}
\hline $\begin{array}{c}\text { Dose } \\
\text { (mg/ kg) }\end{array}$ & \multicolumn{2}{|c|}{ \%MnPCEs } & \multicolumn{2}{c|}{ \%MnNCEs } & \multicolumn{2}{c|}{ PCE \% } & \multicolumn{2}{c|}{ P/N } \\
\hline & Before & After & Before & After & Before & After & Before & After \\
\hline 0.5 & $0.55 \pm 0.04$ & $0.57 \pm 0.05^{\mathrm{ns}}$ & $0.08 \pm 0.02$ & $0.08 \pm 0.01^{\mathrm{ns}}$ & $66.26 \pm 1.64$ & $66.07 \pm 1.57^{\mathrm{ns}}$ & $2.03 \pm 0.12$ & $1.84 \pm 0.17^{\mathrm{ns}}$ \\
\hline 1 & $0.58 \pm 0.06$ & $0.63 \pm 0.07^{\mathrm{ns}}$ & $0.02 \pm 0.01$ & $0.01 \pm 0.01^{\mathrm{ns}}$ & $66.81 \pm 1.29$ & $64.20 \pm 2.35^{\mathrm{ns}}$ & $1.99 \pm 0.14$ & $1.97 \pm 0.13^{\mathrm{ns}}$ \\
\hline 2 & $0.62 \pm 0.05$ & $0.68 \pm 0.07^{\mathrm{ns}}$ & $0.12 \pm 0.01$ & $0.13 \pm 0.02^{\mathrm{ns}}$ & $58.34 \pm 1.74$ & $58.08 \pm 1.65^{\mathrm{ns}}$ & $1.43 \pm 0.10$ & $1.36 \pm 0.13^{\mathrm{ns}}$ \\
\hline 4 & $0.65 \pm 0.05$ & $0.73 \pm 0.04^{\mathrm{ns}}$ & $0.16 \pm 0.03$ & $0.18 \pm 0.03^{\mathrm{ns}}$ & $61.89 \pm 1.49$ & $60.29 \pm 0.64^{\mathrm{ns}}$ & $1.64 \pm 0.11$ & $1.52 \pm 0.04^{\mathrm{ns}}$ \\
\hline 6 & $0.63 \pm 0.08$ & $0.81 \pm 0.09^{\mathrm{ns}}$ & $0.14 \pm 0.02$ & $0.18 \pm 0.02^{\mathrm{ns}}$ & $68.36 \pm 1.39$ & $65.92 \pm 2.45^{\mathrm{ns}}$ & $2.18 \pm 0.14$ & $1.99 \pm 0.19^{\mathrm{ns}}$ \\
\hline \multicolumn{8}{|c|}{ Table 2: In vivo micronucleus analysis in peripheral blood of Swiss mice } \\
before and after treatment with Zinc oxide nanorods
\end{tabular}

\% MnPCEs: percent incidence of micro nucleated polychromatic erythrocytes, \% MnNCEs: percent incidence of micro nucleated normochromic erythrocytes, PCE\%: percentage of Polychromatic erythrocytes, P/N: ratio of polychromatic erythrocytes to normochromic erythrocytes. Statistical analysis performed with paired t-test and data expressed in mean $\pm S E M(n=6)$ before and after treatment with Zinc oxide nanorods, ns=non-significant, $\mathrm{P}>0.05$.

\begin{tabular}{|c|c|c|c|}
\hline \multirow[b]{2}{*}{ Group } & \multirow{2}{*}{ Dose (mg/kg) } & \multicolumn{2}{|c|}{ Tail Length $(\mu \mathrm{m})$} \\
\hline & & Before & After \\
\hline II & 0.5 & $3.358 \pm 0.22$ & $3.526 \pm 0.21^{\mathrm{ns}}$ \\
\hline III & 1 & $3.138 \pm 0.10$ & $3.029 \pm 0.08^{\mathrm{ns}}$ \\
\hline IV & 2 & $3.212 \pm 0.33$ & $3.226 \pm 0.09 \mathrm{~ns}$ \\
\hline $\mathrm{V}$ & 4 & $3.762 \pm 0.11$ & $3.892 \pm 0.27 \mathrm{~ns}$ \\
\hline VI & 6 & $3.444 \pm 0.13$ & $4.025 \pm 0.15^{\mathrm{ns}}$ \\
\hline
\end{tabular}

Measurement of DNA damage as a measure of comet tail length $(\mu \mathrm{m})$. Statistical analysis performed with paired t-test and data expressed in mean \pm SEM $(n=6)$ before and after treatment with Zinc oxide nanorods, $n s=$ non-significant, $P>0.05$.

\begin{tabular}{|c|c|c|c|c|c|c|}
\hline Groups & Dose (mg/kg) & Gaps & Breaks & Total No. of SCAs & Total SCAs/Cell & \% Mitotic Index \\
\hline I & - & $1.00 \pm 0.71$ & $0.16 \pm 0.26$ & $2.33 \pm 1.86$ & $0.0116 \pm 0.009$ & $5.7 \pm 1.75$ \\
\hline II & 0.5 & $1.33 \pm 0.68$ & $0.17 \pm 0.25$ & $3.00 \pm 1.79$ & $0.0150 \pm 0.008^{\mathrm{ns}}$ & $5.8 \pm 1.60^{\mathrm{ns}}$ \\
\hline III & 1 & $1.33 \pm 0.93$ & $0.25 \pm 0.42$ & $3.17 \pm 2.64$ & $0.0158 \pm 0.013^{\mathrm{ns}}$ & $6.0 \pm 2.10^{\mathrm{ns}}$ \\
\hline IV & 2 & $1.58 \pm 0.74$ & $0.33 \pm 0.61$ & $3.83 \pm 2.04$ & $0.0191 \pm 0.010^{\mathrm{ns}}$ & $6.5 \pm 1.87 \mathrm{~ns}$ \\
\hline V & 4 & $1.75 \pm 0.94$ & $0.42 \pm 0.38$ & $4.33 \pm 2.06$ & $0.0216 \pm 0.011^{\mathrm{ns}}$ & $6.3 \pm 2.06^{\mathrm{ns}}$ \\
\hline VI & 6 & $1.67 \pm 0.93$ & $0.67 \pm 0.52$ & $4.66 \pm 2.65$ & $0.0233 \pm 0.013^{\mathrm{ns}}$ & $6.6 \pm 2.16^{\mathrm{ns}}$ \\
\hline \multicolumn{7}{|l}{ Table 4: In vivo bone marrow chromosome analysis in Swiss mice treated with zinc oxide nanorods } \\
\end{tabular}

The total number of structural chromosomal aberrations observed in zinc oxide treated groups were compared with untreated mice. The number of dividing cells observed for each treatment were expressed in terms of percentage mitotic index. Statistical analysis was done by one way ANOVA followed by Dunnett's post-test. Data expressed as mean \pm SD ( $n=6)$, ns=non-significant, $P$ $>0.05$

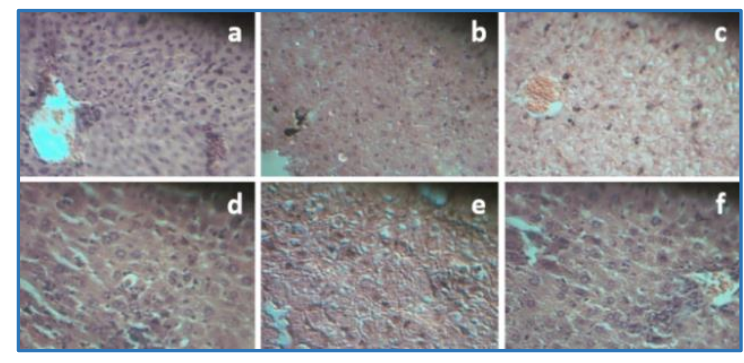

Fig. 1: Histopathological analysis of liver tissues. a: Control (untreated), (b-f: Zinc oxide nanorods treated); b: $0.5 \mathrm{mg} / \mathrm{kg}, \mathrm{c:} 1$ $\mathrm{mg} / \mathrm{kg}$, d: $2 \mathrm{mg} / \mathrm{kg}$, e: $4 \mathrm{mg} / \mathrm{kg}, f: 6 \mathrm{mg} / \mathrm{kg} .1 \mathrm{mg} / \mathrm{kg}$ treated mice showed foamy degenerative hepatocytes. 0.5, 2, 4, 6 showed thick cell trabeculae and dilated congested vessels

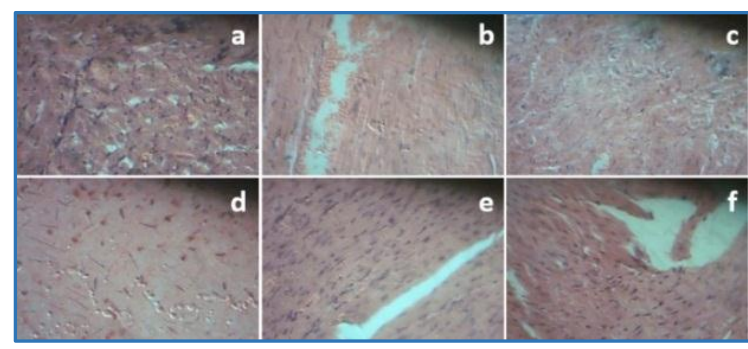

Fig. 2: Histopathological analysis of heart tissues. a: Control (untreated), (b-f: Zinc oxide nanorods treated);

b: $0.5 \mathrm{mg} / \mathrm{kg}, \mathrm{c:} 1 \mathrm{mg} / \mathrm{kg}, \mathrm{d}: 2 \mathrm{mg} / \mathrm{kg}, \mathrm{e:} 4 \mathrm{mg} / \mathrm{kg}, \mathrm{f}: 6 \mathrm{mg} / \mathrm{kg}$. All zinc oxide nanorods treated mice showed no signs of necrosis and lymphatic infiltration

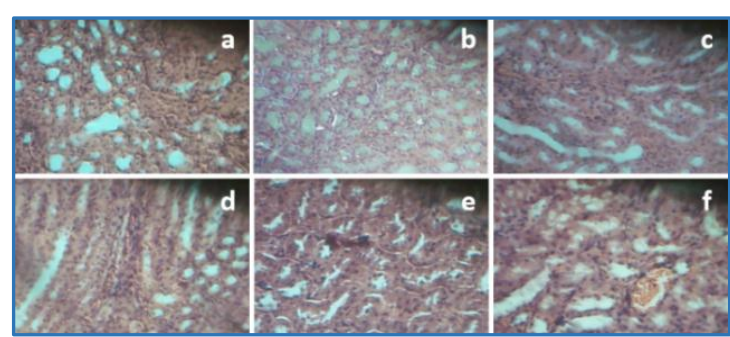

Fig. 3: Histopathological analysis of kidney tissues. a: Control (Untreated), (b-f: Zinc oxide nanorods treated); b: $0.5 \mathrm{mg} / \mathrm{kg}, \mathrm{c}: 1$ $\mathrm{mg} / \mathrm{kg}, \mathrm{d}: 2 \mathrm{mg} / \mathrm{kg}, \mathrm{e}: 4 \mathrm{mg} / \mathrm{kg}, \mathrm{f:} 6 \mathrm{mg} / \mathrm{kg}$. All treated groups showed no signs of kidney infiltration and damage. The figures depicts normal renal parenchyma with glomeruli and renal tubules

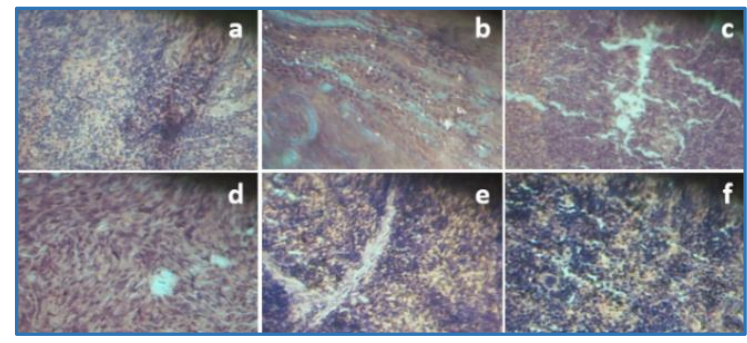

Fig. 4: Histopathological analysis of spleen tissues. a: Control (Untreated), (b-f: Zinc oxide nanorods treated); b: $0.5 \mathrm{mg} / \mathrm{kg}, \mathrm{c}: 1$ $\mathrm{mg} / \mathrm{kg}, \mathrm{d}: 2 \mathrm{mg} / \mathrm{kg}, \mathrm{e}: 4 \mathrm{mg} / \mathrm{kg}, \mathrm{f}: 6 \mathrm{mg} / \mathrm{kg}$. All treated groups show normal spleen histology with lymphoid follicles except for 2 $\mathrm{mg} / \mathrm{kg}$ treated group with irregular dilated vascular channels surrounded by benign spindle cells 


\section{DISCUSSION}

Nanoparticles and their clinical use are rapidly increasing and with the increase in exposure to humans, it is becoming more important to screen for their carcinogenic and mutagenic potential. The results of this study indicate that $\mathrm{ZnO}$ nanorods (Up to $6 \mathrm{mg} / \mathrm{kg}$ ) were not genotoxic which are estimated by micronucleus assay, chromosomal aberration assay and alkaline comet assay. Although ZnO NPs are believed to be nontoxic and biocompatible, there are currently a small number of reports in the literature demonstrating that they could exert negative cellular responses. Exposure of ZnO NPs has been associated with inflammatory responses and cytotoxicity, but there are only few studies that have considered the DNA damaging potential of ZnO NPs.

The present study was an effort to evaluate the genotoxic potential of ZnO NPs (Nanorods), in Swiss albino mice, in relevance to the doses that can be likely exposed to humans. This is the first study which evaluated in vivo genotoxicity of $\mathrm{ZnO}$ nanorods, exposed to mice orally using three standard test systems micronucleus assay, alkaline comet assay, chromosomal aberration assay.

Micronucleus assay results showed no significant increase in percent incidence of micronucleated polychromatic erythrocytes (\% MnPCEs) out of 2000 polychromatic erythrocytes counted for each animal. Along with MnPCEs, another 1000 erythrocytes were separately counted for each animal under treatment. The results of MnNCEs\%, PCE\% and ratio of $\mathrm{P} / \mathrm{N}$ showed no observable difference in the values before and after treatment with $\mathrm{ZnO}$ nanorods. These results indicate that $\mathrm{ZnO}$ nanorods at the current treatment conditions didn't cause clastogenic effect in mature erythrocytes (\% MnNCEs). Further, the PCE\% and ratio of $\mathrm{P} / \mathrm{N}$ indicates that the number of polychromatic erythrocytes percentage counted for analysis of MnPCEs were almost same in all the groups under study, which indicates a baseline for evaluation of genotoxic events.

As supposing higher dose $6 \mathrm{mg} / \mathrm{kg}$ to show greater number of micronuclei formation in accordance from low dose $0.5 \mathrm{mg} / \mathrm{kg}$, the entire four parameters evaluated using micronucleus assay demonstrated no dose effect relationship. These results of micronucleus assay were in accordance with earlier report[20] in mouse bone marrow cells where mice were exposed to $\mathrm{ZnO}$ NPs by inhalation route. The variation in cytotoxicity in present in vivo study from earlier reported in vitro cytotoxicity studies of ZnO NPs may attributable to low doses selection, internal defensive mechanism and also nanoparticle size. To support our data, a study pertaining to cytotoxic evaluation by Hanley et al 2009[21] showed sized dependent cytotoxicity, where $4 \mathrm{~nm}$ ZnO NPs were more toxic than $13 \mathrm{~nm}$ and $20 \mathrm{~nm} \mathrm{ZnO} \mathrm{NPs.}$

A means of detecting in vivo genetic activity is to examine mitotically active cells that have been arrested at metaphase for structural changes and re-arrangement of their chromosomes. Chromosome analysis of bone marrow cells in vivo has become a standard method for testing for the potential mutagenic effects of viruses, radiation, drugs, and chemical pollutants.[22] The results of chromosomal aberration assay demonstrated no significant increase in the induction of structural chromosomal aberrations by $\mathrm{ZnO}$ nanorods upon comparison with that of control untreated groups. This indicates that $\mathrm{ZnO}$ nanoparticulate dispersion employed showed no chromosomal damage at selected dose.
In continuation, mitotic index demonstrates the cell proliferation rate. And influence of any chemical which alters mitotic index is supposed to have capability in varying cell proliferation. In this study, percentage mitotic index showed no significant difference, demonstrating no major effect of $\mathrm{ZnO}$ nanorods on cell proliferation. On contrary, Dufour et al 2006 and Someya et al 2008 first demonstrated that chromosomal aberrations were induced by ZnO NPs with mean diameter of $100 \mathrm{~nm}$ were enhanced by UV light, with increased clastogenicity under pre-irradiation (PI) and simultaneous irradiation (SI) conditions than in dark.[11] Chromosomal aberrations were observed in human dental pulp cells treated with $\mathrm{ZnO}$.[13] This difference in variation of results from the current work to previous reports suggests that those effects that are produced by zinc oxide nanoparticles under confined in vitro conditions might not have translated under in vivo conditions.

Similarly, the comet assay was performed in order to evaluate the potential of $\mathrm{ZnO}$ nanorods to cause DNA strand breaks. The results showed that no significant change in comet tail length which was evident up on comparing to comet tail lengths obtained from the same animal before treatment. The results of these test found that DNA damage was not induced by $\mathrm{ZnO}$ nanorods in mice. These findings contrast from earlier reports, in which ZnO NPs have shown to cause statistically significant DNA damage at concentrations of $5 \mu \mathrm{g} / \mathrm{mL}$ and $0.8 \mu \mathrm{g} / \mathrm{mL}$ after an exposure period of 6 hours in human epidermal cells (A431).[23] And a dose dependent increase in DNA damage in human sperm cells under pre-irradiated and simultaneous irradiation condition.[12] Similarly, another study reported by Ali D et al. 2012[24] in digestive gland cells treated with ZnO NPs at concentration of $32 \mu \mathrm{g} / \mathrm{mL}$ for 24 and 96 hours elicited DNA damage observed by comet assay. The present result also contradicts with the in vitro comet assay done on HEp-2 cells by Osman IF et al 2010[25] where a concentration and time dependent increase in DNA damage was observed upon treatment with ZnO NPs.

The results of the present study are in line with report of Landsiedel et al 2010[20] on evaluation of genotoxicity in lung cells of mice for DNA damage by alkaline comet assay after exposure with ZnO NPs by inhalation route.

In supporting SOS chromotest by Nam S-H et al 2013[26] reports ZnO NPs as non-genotoxic along with some metal and metal oxide nanoparticles tested there in. It is well known that nanoparticles in general can enter the cellular environment owing to their nano size, and may cause tissue damage. The earlier toxicity study reported that stomach, liver, heart and spleen are the target organs at dose of $1 \mathrm{~g} / \mathrm{kg}$ to $5 \mathrm{~g} / \mathrm{kg}$ in mice.[27] The present study report showed no gross pathological variations of liver, spleen, heart, and kidney in comparison to control group. ZnO NPs at a dose of $0.2 \mathrm{~mL}$ orally from a $30 \mathrm{mg} / \mathrm{mL}$ suspension, showed tissues of heart, lung, liver, kidney cells to turn abnormal, after seven day consecutive treatment.[5]

These disagreements of present histopathological findings from previous reports may be attributable to the high dose range used in the study done by Wang et al 2008[27] compared to the low dose range of $0.5-6 \mathrm{mg} / \mathrm{kg}$ done in this study. Moreover, shape of the nanoparticles also plays a vital role in their toxicological interactions. Number of studies have shown that the shape of a nanoparticle can highly influence their rate of uptake.[28] Spherical nanoparticles 
show higher uptake than nanorods.[29] The selection of the ZnO NPs dose and shape of the nanoparticles in this study is purely based on the ZnO NPs strength and type used in potential consumer products, dental and cosmetic products, etc.

Thus, the result of present study states that $\mathrm{ZnO}$ nanorods are not genotoxic in in vivo test conditions. Overall, the results add to the still limited database on genotoxicity test results concerned to $\mathrm{ZnO}$ NPs as the present results stating $\mathrm{ZnO}$ NPs are not genotoxic and that the previous reports (Majorly in vitro) illustrating ZnO NPs clastogenic and genotoxic potential. Therefore, further studies are needed with wider range of $\mathrm{ZnO}$ NPs doses to assess the toxicity effects.

In summary, the study showed no clastogenic and genotoxicity in mice treated with $\mathrm{ZnO}$ nanorods for seven days in drinking water dispersed at lowest exposure doses, which are commonly used in clinical products.

\section{CONCLUSIONS}

In the present study, we have evaluated in vivo genotoxicity of zinc oxide nanoparticles bearing rod shape with $18 \mathrm{~nm}$ size in Swiss albino mice in order to comprehend the toxicity and/or safety concern of zinc oxide nanorods. The results of this study suggest that administration of zinc oxide nanorods orally for seven consecutive days at the selected dose range $(0.5-6 \mathrm{mg} / \mathrm{kg})$ is safe and has not produced any apparent DNA damage. In view of the wide applications owing to zinc oxide nanoparticles in biomedical and cosmetic fields, the results aid a support of evidence of safety and their usage. Further, thorough experimental works in different human exposure routes like dermal, inhalation and others are also to be evaluated to understand the safety and risk towards humankind.

\section{REFERENCES}

1. Nohynek GJ, Lademann J, Ribaud C, et al. Grey goo on the skin? Nanotechnology, cosmetic and sunscreen safety. Critical Reviews in Toxicology 2007;37(3):251-77.

2. Rajendra R, Balakumar C, Ahammed HAM, et al. Use of zinc oxide nano particles for production of antimicrobial textiles. International Journal of Engineering, Science and Technology 2010;2(1):202-8.

3. Comparelli R, Cozzoli PD, Curri ML, et al. Photocatalytic degradation of methyl-red by immobilised nanoparticles of TiO2 and ZnO. Water Sci Technol 2004;49(4):183-8.

4. Tang H, Mi Yan, Xingfa Ma, et al. Gas sensing behavior of polyvinylpyrrolidone-modified $\mathrm{ZnO}$ nanoparticles for trimethylamine. Sensors and Actuators B Chemical 2006;113(1):324-8.

5. Zheng Y, Li Ranzhong, Wang Y. In vitro and in vivo biocompatibility studies of $\mathrm{ZnO}$ nanoparticles. International Journal of Modern Physics B 2009;23(67):1566-71.

6. Yang H, Liu C, Yang D, et al. Comparative study of cytotoxicity, oxidative stress and genotoxicity induced by four typical nanomaterials: the role of particle size, shape and composition. Journal of Applied Toxicology 2009;29(1):69-78.

7. Lin $\mathrm{W}, \mathrm{Xu} \mathrm{Y}$, Huang $\mathrm{C}-\mathrm{C}$, et al. Toxicity of nano- and micro-sized $\mathrm{ZnO}$ particles in human lung epithelial cells. Journal of Nanoparticle Research 2009;11(1):25-39.
8. Deng X, Luan Q, Chen W, et al. Nanosized zinc oxide particles induce neural stem cell apoptosis. Nanotechnology 2009;20(11):115101.

9. Applerot G, Lipovsky A, Dror R, et al. Enhanced antibacterial activity of nanocrystalline $\mathrm{ZnO}$ due to increased ROS-mediated cell injury. Advanced Functional Materials 2009;19(6):842-52.

10. Yoshida R, Kitamura D, Maenosono S. Mutagenicity of water-soluble $\mathrm{ZnO}$ nanoparticles in Ames test. The Journal of Toxicological Sciences 2009;34(1):119-22.

11. Dufour EK, Kumaravel T, Nohynek GJ, et al. Clastogenicity, photo-clastogenicity or pseudo-photoclastogenicity: genotoxic effects of zinc oxide in the dark, in pre-irradiated or simultaneously irradiated Chinese hamster ovary cells. Mutat Res 2006;607(2):215-24.

12. Gopalan RC, Osman IF, Amani A, et al. The effect of zinc oxide and titanium dioxide nanoparticles in the Comet assay with UVA photoactivation of human sperm and lymphocytes. Nanotoxicology 2009;3(1):33-9.

13. Someya H, Higo Y, Ohno M, et al. Clastogenic activity of seven endodontic medications used in dental practice in human dental pulp cells. Mutat Res 2008;650(1):39-47.

14. Musarrat J, Saquib Q Azam A, et al. Zinc oxide nanoparticles-induced DNA damage in human lymphocytes. International Journal of Nanoparticles 2009;2(1-6):402-15.

15. Trouiller B, Reliene R, Westbrook A, et al. Titanium dioxide nanoparticles induce DNA damage and genetic instability in vivo in mice. Cancer Research 2009;69(22):8784-9.

16. Westbrook AM, Wei B, Braun J, et al. Intestinal mucosal inflammation leads to systemic genotoxicity in mice. Cancer Res 2009;69(11):4827-34.

17. Chuang $\mathrm{CH}, \mathrm{Hu}$ ML. Use of whole blood directly for single-cell gel electrophoresis (comet) assay in vivo and white blood cells for in vitro assay. Mutation Research 2004;564(1):75-82.

18. Nadin SB, Vargas-Roig LM, Ciocca DR. A silver staining method for single-cell gel assay. J Histochem Cytochem 2001;49(9):1183-6.

19. Savage JR. Classification and relationships of induced chromosomal structural changes. J Med Genet 1976;13(2):103-22.

20. Landsiedel R, Ma-Hock L, Ravenzwaay BV, et al. Gene toxicity studies on titanium dioxide and zinc oxide nanomaterials used for UV-protection in cosmetic formulations. Nanotoxicology 2010;4:364-81.

21. Hanley C, Thurber A, Hanna C, et al. The influences of cell type and $\mathrm{ZnO}$ nanoparticle size on immune cell cytotoxicity and cytokine induction. Nanoscale Res Lett 2009;4(12):1409-20.

22. Bakare AA, Ademeso MM, Adetunji OA, et al. Pharmaceutical effluent induced chromosome aberration in rat bone marrow cells. Archives of Applied Science Research 2011;3(2):345-52.

23. Sharma V, Shukla RK, Saxena N, et al. DNA damaging potential of zinc oxide nanoparticles in human epidermal cells. Toxicol Lett 2009;185(3):211-8.

24. Ali D, Alarifi S, Kumar S, et al. Oxidative stress and genotoxic effect of zinc oxide nanoparticles in freshwater snail Lymnaea luteola L. Aquat Toxicol 2012;124125:83-90. 
25. Osman IF, Baumgartner A, Cemeli E, et al. Genotoxicity and cytotoxicity of zinc oxide and titanium dioxide in HEp-2 cells. Nanomedicine (Lond) 2010;5(8):1193-203.

26. Nam SH, Kim SW, An YJ. No evidence of the genotoxic potential of gold, silver, zinc oxide and titanium dioxide nanoparticles in the SOS chromotest. J Appl Toxicol 2013;33(10):1061-9.

27. Wang B, Feng W, Wang M, et al. Acute toxicological impact of nano- and submicroscaled zinc oxide powder on healthy adult mice. Journal of Nanoparticle Research 2008;10(2):263-76.
28. Muller J, Huaux F, Fonseca A, et al. Structural defects play a major role in the acute lung toxicity of multiwall carbon nanotubes: toxicological aspects. Chem Res Toxicol 2008;21(9):1698-705.

29. Chithrani BD, Chan WC. Elucidating the mechanism of cellular uptake and removal of protein-coated gold nanoparticles of different sizes and shapes. Nano Lett 2007;7(6):1542-50. 